\title{
The anthropology of Islam in Europe A double epistemological impasse
}

\author{
Nadia Fadil \\ March 2019 \\ Forthcoming at Annual Review of Anthropology
}

\begin{abstract}
:
This paper reviews the main trends in the anthropological scholarship of Islam in Europe by examining how this body of work through the lens of what I call a 'double epistemological impasse'. The first one refers to the historical marking of Islam as Europe's 'other', the second one concerns anthropology's vexed relationship with religions traditions in general, and Islam in particular, in their ontological claim-making. Through the organisation of the literature into three key figures (the Muslim as migrant, as Islamist and ethical subject), this paper will try to unearth the way in which this double impasse has impacted upon and informed anthropological scholarship on Islam in Europe.

Europe - Islam - Race - Subaltern - Islamist - Migrant - Ethics

Acknowledgement :

I am grateful for the stimulating and thought-provoking comments of Christian Suhr Nielsen, Sarah Bracke, Annelies Moors, Martijn de Koning, Hafsa Oubou, Sahar Sadadji and the anonymous reviewer of ARA on earlier versions of this paper.
\end{abstract}


“il n’y a, dans la pratique d'une religion dominée, et dominée au point de n'être plus qu'un critère d'identification sociale, rien qui puisse échapper à la règle des réinterprétations et des surdéterminations" 1

Abdelmalek Sayad (2014 [1987]: 147)

In December 2018, the Dutch public broadcasting service NPO aired the show Moslims zoals wij, a Dutch remake of the British show Muslim like us launched in 2016. Seven Dutch and one Belgian Muslim were featured spending ten days together in a house in Roermond, a city in the South-East of the Netherlands. The candidates had been selected according to their ethnicity, gender, sexuality and distinct views on Islam. The selected participants ranged from the newly converted native Dutch, orthodox Somali preacher, pious and veiled Indonesian, to the non-practicing Afghan, sexy yet religiously conservative Moroccan fashion vlogger and lesbian Turk-Indonesian. Yet in difference to what the title suggests, the show did much more than simply represent Muslims in a way that reassured the Dutch audience that "they" weren't that different from "us". During those ten days, several facets of the participants' religious identity and practice were explored as viewers witnessed the struggle all candidates underwent in reconciling their - at times very - contrasting views on Islam and the sentiment of belonging to the same community of faith. This struggle, furthermore, culminated when the pious Fitria admitted to the non-practicing Hazjir that, and on the basis of the conduct she had witnessed in the last five days, she could not consider him a Muslim. The harsh judgement of the otherwise very kind and warm Fitria resulted in the withdrawal of Hazjir from the group, which triggered an internal discussion on the appropriateness of her words and the right to judge

\footnotetext{
1 "There is, in the practice of a dominated religion, and dominated to the extent of being nothing more than a marker of social identification, nothing that can escape the rule of re-interpretation and overdetermination"
} 
someone else's conduct. The Dutch TV Show Muslim like us was overwhelmingly positively received, as commentators praised the diversity and authenticity of each character. ${ }^{2}$ The framing and reception of the show, however, also revealed a series of tensions that will be of interest for our purpose. The first one revolves around the necessity to deconstruct the binary representations of Muslims as "other" - i.e. Muslims (are) like "us", while at the same time acknowledging the distinctiveness of their lived and religious experiences. The second one is to highlight the internal tensions and contradictions that traverse this community, while also recognizing a certain coherence - as is exemplified in the show through the recitation, by all participants, of the Surat al-Fatiha (the Opening) at the start of each episode. I take these tensions as a starting point for this review, for I want to suggest that anthropological scholarship on Islam in Europe is equally informed by a similar set of tensions which revolve around the desire to account for the ethical subjectivity of Muslims, while at the same time downplaying it.

Two central aims inform this review. The first one is to offer an overview of the current trends in anthropological scholarship on Islam in Europe, with a particular focus on the literature on North-Western Europe. The attentive reader will note that countries such as France, the Netherlands, the UK, Belgium and Germany are overrepresented in this review. Southern-European countries, on the other hand, only cursorily appear, and Eastern-Europe is absent. This limited focus is partially the result of the authors' own bias and focus on NorthWestern Europe, but it also reflects the dominant weight of these countries in the current debates on Islam in Europe, which translate in an overrepresentation in the scholarship. A second purpose is more theoretical, and it is to offer a critical reflection on state of (anthropological) knowledge production on Islam in Europe and how the latter is marked by

\footnotetext{
${ }^{2}$ A critical, though sympathetic, review of the show can, for instance, be found in the largely read blog of anthropologist Martijn de Koning. URL: http://religionresearch.org/closer/2018/12/24/moslimzoalswij-eenslotbespreking-spiegel/ (accessed 19 March 2019)
} 
what I will describe as a double epistemological impasse. The term impasse, originally a French word, is generally used to refer to a situation of "deadlock" (Merriam-Webster), or "a situation in which progress is impossible, especially because the people involved cannot agree" (Cambridge Dictionary). By invoking the image of an impasse, I want to allude to a structural condition that informs the condition of knowledge production on Islam in Europe and which is tied with the historical representation of Islam as Europe's "other" on the one hand, and the discomfort of social sciences (including anthropology) with the ontological claim-making of monotheistic religious traditions. One of the explicit aims of this review is to unearth the way in which this double impasse structures anthropological scholarship. After briefly sketching the historical and theoretical contours of this argument, the reviewed literature will be tentatively organised around three "key figures" (Salazar 2017): the migrant, the Islamist, and the Muslim as ethical subject. ${ }^{3}$

\section{Islam in Europe: two epistemological impasses}

Whereas the first Muslims arrived in the Iberian Peninsula less than a century after the first revelations of the message to the Prophet Muhammad in Mecca in the $7^{\text {th }}$ century (Goody 2004), Muslim's $20^{\text {th }}$ century presence in Europe is often marked as a 'new' development (see for instance Kepel 1987). Estimated at 25,8 Million, Muslims represent one of the fastest growing religious community in the continent, ${ }^{4}$ a reality which has resulted in a succession of debates on the (Judeo-)Christian character of Europe (Nathan \& Toploski 2016), secularism (Habermas 2008), gender and sexuality (Scott 2007) or, more recently, security and

\footnotetext{
${ }^{3}$ In a special issue on the subject, the anthropologist Noel Salazar draws on Raymond William's work to define key figures as essentially contested concept yet which fulfill a function in "binding words in certain activities and their interpretation; they are significant, indicative words in certain forms of thought. Certain uses bound together certain ways of seeing culture and society" (Williams quoted in Salazar, 2017: 7).

${ }^{4}$ Estimations for 2016 by the Pew Research Centre (2017: 4). These estimations include the 28 EU nations and Norway and Switzerland. Several authors have however also warned for the conceptual difficulties one encounters in estimating properly the number of Muslims as they are based primarily on people's country of origin and say less about one's actual confessional orientation (see for instance Brown 2000).
} 
counterterrorism (Khosrokhavar 2016, Truong 2018). As noted by several scholars, these societal tensions show that the so-called "Muslim Question" (Norton 2013) operates, today, as one of main cultural fault lines around which the idea of Europe becomes debated and reimagined (Asad 2003). One of the recurrent elements in these debates is indeed the idea that Europe and Islam represent discrete, or even opposing, entities that have come together in an unprecedented way.

This idea of Islam, as Europe's 'other' has, however, not always been straightforward. In their historical review on the relationship between Europe and Islam, the French historians Henry Laurens, Gilles Veinstein and John Tolan (2009) remind us that the Muslim has not always existed as a discrete subject, not more than the European. In the French and English language the term Muslim only emerges around the $16^{\text {th }}$ century, that of Islam in 1697 in French and in 1818 in English - almost eight-hundred years after the first appearance of Muslims on European land (Laurens et. al. 2009: 9). ${ }^{5}$ Muslims were not targeted as a uniform whole, but the assignations used were much more complex ('Turk', 'Arab', 'More', 'Mohammedan', 'Saracen'). The Crusades, for instance, where not only a moment of strong political adversity, but they also lead to "an interpenetration of the populations through trade and proximity" (Goody 2004: 33). This, at once, highlights the polyform, contradictory and complex relationships the different European political entities, monarchies and empires entertained with the Muslim world (Aydin 2017). The idea of Islam and Europe, as distinct cultural and geopolitical tropes, will however become more explicit throughout the modern period. This is as much the result of large transformations internal to the continent (Reformism, the expulsion of Muslims and Jews from Spain and the French Revolution) as of the French and British imperial expansions into the New World and the Orient, which incited a clearer demarcation of the "true

\footnotetext{
${ }^{5}$ It is important to stress that the history sketched by Laurens, Veinstein and Tolan (2009) largely follows a NorthWestern European track, a different genealogy needs to be sketched for the case of the Iberian Peninsula where Islam has been a constitutive factor between the $7^{\text {th }}$ and $15^{\text {th }}$ century. For a different genealogy that also accounts for the Iberian (Arabs), Balkan (Ottomans) and Northern-European (Mongols) track see Goody (2004: 12).
} 
religion" - i.e. Christianity (Masuzawa 2015, Said 1978, Matar 1999). An ostensible discourse of polarity will gradually overshadow the interconnections and exchanges that have historically marked the relationship between Europe and Islam (Coller 2011, Aydin 2017), as the idea of Europe will gain a more explicit identity and weight around notions of modernity, progress and rationality (Laurens et al. 2009).

This period, however, also coincides with a new relationship of "closeness" (Said 1978: 4) towards Islam, as Muslims become gradually incorporated as colonial subjects into the various European colonies. Two distinct views will simultaneously inform the administrative practices towards Muslim populations (Davidson 2012, Sbaï 2018). The first one draws on the idea that Islam is a totality that is fundamentally distinct and inassimilable to the Enlightenment values and that Muslims cannot be separated from their religious practice, something the historian Naomi Davidson describes as "embodied Islam", and which she sees to be materialised in the French colonies through the code de l'indigénat, which also produced clear racial demarcations and hierarchies between Muslims and Jews (Davidson 2012: 15, 27). A clear example can be found in the work of the renown French philologist, Ernest Renan, who will recall the relationship to Islam in highly antagonistic terms in his inaugural lecture of 1862 at the Collège de France, one of the country's highest seats of knowledge (see also Said 1978, Masuzawa 2015):

“L’Islam est la plus complète négation de l’Europe, l’islam est le fanatisme...; l'islam est le dédain de la science, la suppression de la société civile; c'est l'épouvantable simplicité de la pensée sémitique, rétrécissant le cerveau humain, le fermant à toute l'idée délicate, à tout sentiment fin, à toute recherche rationnelle, pour le mettre en face 
d'une éternelle tautologie: Dieu est Dieu"' (Renan cited in Laurens et al. 2009: 332222)

This first view is complemented by a second one, which rather stresses the need for reform and the possibility of assimilation of Muslims into European enlightenment. This second perspective will convey the idea that a modernised elite can be formed through education, and incorporated into the newly established colonial structures. This view will also give nascence to the well-known demarcation between "bad Muslims" (the Pan-Islamist purists) and "good Muslims" (Muslims as redeemable subjects). Such a position can be found, for instance, in the work of Dutch Orientalist and advisor to the Dutch crown in Indonesia, Christian Snouck Hurgonje, who argued for the necessity to selectively co-opt an educated elite whilst at the same time waging war against Pan-Islamic purists (Kennedy \& Valenta 2008, Fadil, de Koning \& Raggazi 2019). In the French context, Catholic figures such as Robert Montagne played an important role in the establishment of administrative structures like the French Haut Comité Meditterranean (HCM) or the Centre des Hautes Etudes de l'administration Musulmane (CHEAM), that were seen as a counterweight to the pan-Islamic tendencies (Sbaï 2018: 210212). Several studies have extensively documented the postcolonial continuations of these governmental logics in today's relationship to Islam in (and outside) Europe (Maussen, Bader \& Moors 2012, Mamdani 2004). ${ }^{7}$ This continuation is, however, also premised on a knowledge production on this religious community. One of the outstanding questions is, therefore, to understand how this historical gaze on the (benign and/or malicious) nature of Islam has

\footnotetext{
6 "Islam is the most complete negation of Europe, Islam means fanaticism.. Islam is the disavowal of science, the oppression of the civil society, it's the terrible simplicity of the Semitic mind, which reduces the human brain and closes it off from any subtle idea, any delicate feeling, any rational inquiry, to end up with an indefinite tautology: God is God" (my translation - NF)

${ }^{7}$ In their edited volume on Muslim communities in Western-Europe during the interbellum, the historians Grötz and Ryad (2014) note, however, that most European countries dealt "benevolently" with the first Islamic organizations, as they saw these Muslim minorities primarily as representatives of their country of origin (2014: 26).
} 
fundamentally structured contemporary scholarship on Islam in Europe, which brings me to the two epistemological impasses which are at the heart of this review.

As a relative late-comer to the anthropological discipline, the study of Islam was for long assigned to philologist (McLoughlin 2007, Varisco 2005, Masuzawa 2015). Anthropologists considered Islam to be "too familiar", or too "un-contentious and relatively unchanging" to be worthy of any interest (Lindholm cited in McLoughlin 2007: 281). Yet as Islam gradually grew into becoming a social-scientific preoccupation, the overpowering presence of the Orientalist gaze, which traps Muslims into a realm of Otherness, became an important point of contention (El-Zein 1977). Weary of these risks, several ethnographers have therefore privileged a perspective that highlights the "ordinariness" of Muslims (Gilsenan 1982). This first difficulty is, however, also entangled with a second one, and which concerns anthropology's vexed relationship with the study of monotheistic religious traditions (in particular Christianity and Islam). Several authors have highlighted anthropology's uneasiness - or what Fenella Cannell has termed a "disciplinary nervousness" (2006: 3) - with regard to religious experiences (Willerslev \& Suhr 2018), in particular when it concerns Christianity. Albeit adopting very distinct views on this question, Robbins (2003) and Marshall (2014) have argued that this discomfort is a reflection of anthropology's own normative (i.c. secular) commitments, for Christianity's epistemological claims are seen to stand in competition with the discipline's efforts to define 'the real'.

The combination of these two problems results in a particular series of complications - or as I will prefer to call them: impasses - when it comes to the study of Islam in Europe: how does one write about the constitutive capacities of Islam without reproducing an Orientalist narrative? I define Islam here, building on the work of Talal Asad, as a discursive tradition which he defines as a heterogeneous set of "discourses that seek to instruct practitioners regarding the correct form and purpose of a given practice that, precisely because it is 
established, has a history" (Asad, 1986: 14). At the heart of Asad's conceptualisation is an attention for the constitutive modalities of these discourses in everyday life: a tradition is not simply a "set of symbols", but equally entails a practical dimension which instructs practitioners to act and reason in a particular way (Mahmood, 2005: 115). Asad's conceptualisation, furthermore, leaves room for a complex understanding of how this occurs, as his model also considers heterogeneity, conflict and disagreement to be inherent to any tradition (1986: 16). Documenting the constitutive power of the Islamic tradition in the European space is, however, not an innocent enterprise. In the current context, where interminable debates succeed each other on Islam's compatibility with the European laws and state, it becomes difficult to document the possibly larger 'ambitions' of the adherents of this tradition (such as converting people), in part because of the researchers' own (secular) discomforts, but also because it risks validating dystopian views around the 'Islamisation of Europe'. To the extent that Islam in Europe can be represented, it is often as a compartmentalised religious system (Asad 1993) which inhabits a space of subalternity. ${ }^{8}$ Few anthropologists have reflected on this problem and its effects on scholarship, and when it comes up, it is mostly treated as a methodological question. ${ }^{9}$ One of the central aims of this review is, therefore, to examine how these two impasses, the Orientalist demarcation of Muslims as 'other' and the difficulty of representing Islam as a complex discursive tradition, have

\footnotetext{
${ }^{8}$ In using the Gramscian concept of subaltern, I draw on Gayarti Spivak's (1988) well-known essay who deploys this term to theorize a condition of non-representability, or unspeakability, of (female) colonial subjects in India. Whereas Spivak's work is set as a critique of the epistemic violence she sees at work in the dominant historiographic and philosophical representation of colonial subjects in India, a similar critique can also be made regarding secularism. Reflecting on this question, Saba Mahmood suggests that the epistemic power of secularism lies not so much in the erasure of religious experiences, than in the clear conditioning of the type of "religious claims (that) can be authorized and validated" (Mahmood 2016: 206). Drawing on these two lines of thought, I want to suggest that the dominant hostility towards Islam in the European public space plays an important role in regulating the type of claims Muslims can make and in compartementalizing Islam into a system of symbolic representations.

${ }^{9}$ Well-known is the expectation, on behalf of pious interlocutors, that researchers would convert (either to Islam in case of non-Muslims, or into 'proper' Islamic conduct in the case of Muslim ethnographers). For an example of a discussion of this tension, see Bendixsen 2013 (in particular chapter 2).
} 
fundamentally shaped scholarship on Islam in Europe with a particular focus on its effects upon anthropological studies.

\section{Islam, migration and the problem of integration}

One of the first figures to inform the studies on Islam in Europe, is that of the migrant, in reference to the tens of thousands of workers from North-Africa into France, Belgium or the Netherlands and Turks into Germany who moved into the continent after the second world-war due to the shortage of workers in the coalmine and car industry (Martens 1973, Ath-Messaoud \& Gillette 1976). Largely represented as masculine (for a critique see Pedraza 1991) and "uprooted" (Silverstein 2005: 372), this figure of the migrant is characterised by what the French-Algerian sociologist Abdelmalek Sayad (1999) describes as a "double absence" (Sayad 1999: 20). In his seminal study on Algerian migrants in France, the French-Algerian sociologist uses this formulation to designate the erasure of the multifaceted dimensions of the lives of immigrants in France, and whose existence is primarily grasped in scientific literature in terms of "absence": absence from the home-country, absence from the country of residence. The migrants are, in this early phase, chiefly seen as workers, whose antinomic presence in Europe is characterised by what Sayad describes as an "indefinite temporariness" (provisoire durable) (Sayad 1999: 93, see also Nail 2015: 15, Mandel 2008). A few early studies will, however, pay attention to the importance of religion in the lives of these workers (Hamès 1979, Kastoryano 1987). This will, however, mostly occur in the context of a broader interest in religious adjustments made at the factory or residencies, the so-called "foyers" (Diop 1988), and several studies will also draw on an understanding of Islam as epiphenomenal to the migrants' working conditions (Barou 1985: 208, Withol de Wenden 1985: 222). A notable exception, however, is the anthropological study of Riva Kastoryano, which is one of the early attempts to account for the importance of Islam in the cultural identity of Turkish workers (Kastoryano 1987: 837). 
Anthropologists, in particular, have played an important role in yielding a holistic view on the lives of (Muslim) migrants, by including elements of culture and religion. In the British context, the work of Pnina Werbner's The Migration Process (2002 [1990]) represents a significant intervention due to her critique of the overall passive and disempowering view on migrants' lives in existing scholarship, and the detailed account she offers of the central role of kinship structures and ethnic networks in the creation of a transnational Pakistani entrepreneurial community. An important element in her study is the importance given to women in this process, who had, until then, remained largely invisible (notable exceptions are Andezian 1983). As for Islam, the latter will be primarily apprehended as a social structure that enables the community's self-constitution through collective rites such as praying, fasting, ritual slaughtering or the repatriation of the bodies of the deceased to the home country (Werbner 1990, see also Hamès 1979: 97). This structuralist-functionalist lens will be extremely influential in this early stage and several studies will also attend to the central role of the religious structures in the (social and geographical) mobility of Muslims as well as their integration in the new, migratory, context. We can find it in the studies examining the role of Tariqa or Sufi networks in the migratory context (Lacomba 2000, Bava 2003, Rytter 2013), or the large body of works on mosques. Initially apprehended as what Pierre Nora (1984) calls "lieux de mémoire", topoi that allow for a nostalgic cultivation of the ties with the homeland (Dassetto \& Bastenier 1984), this view will be gradually complicate by later studies that will document the central importance of these "Muslim spaces" (Metcalf 1996) in the adaptation to the European context, and the complex reconfigurations that occur in terms of ethnicity, generation or gender (Sunier 1996, Lewis 1994, Nielsen 1992, Kanmaz 2009, Boender 2007, Eade 1996, Kuppinger 2015, McLoughlin 2005, Verkaaik 2012).

A finaly body of work linked with the figure of the migrant concerns his offspring, the so-called 'second-generation'. This term has been critiqued by several analysts for putting 
European born youth in a perpetual zone of non-belonging (Guenif Soulimas 2000: 42-43, Silverstein 2005, Sayad 1999), and for reproducing a "Manichean view" (Guénif Souilamas 2000: 44) that considers this generation as being stuck between two opposing cultures. Islam, in particular, will be treated as an important site to study this conflict between 'tradition' and 'modernity'. Several early studies will argue that the youth's conservation of Islam, which is largely understood as a coercive tradition, is to be understood as an expression of an “intergenerational loyalty” (Gonzalez-Quijono 1988: 71 \& 74, Lacoste-Djuardin 1992: 69). This secularist view, which assumes the gradual dissipation of religion as generations come to adapt to the European context, will, however, be challenged by a subsequent body of work that will emphasize this continued presence of Islam among the youth by also documenting it's individualised re-appropriation through a demarcation between 'culture' and 'religion' (Jacobsen 2011, de Koning 2008). Such a view is also informed by a theoretical shift into more complex views on identity and ethnicity, wherein multiple forms of attachments are treated as a hallmark of postmodernity (Hall 1987). Islam becomes, within this new theoretical conjuncture, understood as a "new ethnicity" which facilitates an accrued involvement into the European social space (Sunier 1996, Vertovec \& Rogers 1998). This perspective will, furthermore, pave the way for an account of the transnational components this Islamic reality (Mandaville 2001), by also highlighting its integrative dimensions (Amiraux 2001). Yet the question of integration will remain an overarching concern to the extent that demonstrating Islam's 'adaptability' into the European political space will remain an important theme within this body of work. This concern with integration is, furthermore, also strongly interwoven with a second key concern, i.e. that of secularism.

\section{Islamism, secularism and the 'good' Muslim}


The second key figure to appear throughout the literature is that of the fundamentalist, or the Islamist (Sayyid 1997). Like the migrant, the figure of the Islamist is marked as 'other'. Yet his condition of otherness lies less in the disruption of a "national order of things" (Malkki 1993), than in the destabilization and unsettling of a secular order of things (Asad 2003, Harding 1991). The Islamist exists as a "haunting" figure (Derrida 1994), whose imagined ability to overturn the secular ontology (i.e. to Islamize the social world) acts as a continuous source of societal, political and scholarly tension. The year 1989, which signals the end of the cold-war and the world-wide emergence of political Islam as a new global threat (Mamdani 2004), represents an important turning point as it announces a series of important "events" (Meinert and Kapferer, 2015): the Rushdie affair and the first headscarf affair (affaire $d u$ foulard). ${ }^{10}$ Whereas the images of hundreds of angry Muslims demonstrating in the heart of London against Salman Rushdie's The Devil Verses triggered a liberal outcry on Muslims' non-adherence to the European core values (Modood 1990, Asad 1993, Lewis 1994), what started as a banal dispute between a head of school and three teenagers in the Parisian suburb who refused to take off their veil, generated a nationwide controversy that would persist for more than two decades and expand well beyond the French borders (Lorcerie 2005, Bowen 2008, Scott 2007, Fernando 2014). The moral panic around what would come to be known as a 'religious revival' will have important and lasting effects: that of resuscitating a familiar colonial figure - the Islamist - into European debates on Islam in Europe (Laurens 1993, Silverstein 2004). The influential work of the French political scientist Gilles Kepel (1991 [1987], 1994), who first worked on Islamist movements in Egypt, played an important role in linking the Islamic revival observed among French youth with the proselytizing efforts $(\mathrm{da}$ ' $w a)$ of Islamists. His argument, that their socio-economic precariousness and identity struggles are

\footnotetext{
${ }^{10}$ For a critique on 1989 as turning point, see Hajjat \& Mohammed (2013), who consider the workers' strikes in the early eighties as a more significant moment. Another important event is, for the Belgian context, the demonstrations against the American invasion in Benghazi in 1986 (Dassetto \& Bastenier 1987).
} 
instrumentalized for the creation of communitarian spaces (communautarisme) that contradict the French Republican model of integration (1991: 381-384), will be highly influential. The term communautarisme is specific to the francophone debate and reflects a Republican fantasy which imagines the citizen as an individual, stripped from any social or cultural weight, with an unmediated bond with the Republican State and is therefore hostile to community-based initiatives that are seen to stand in the way of this 'Holy Communion' (Scott 2007, Bowen 2006, Fernando 2014).

The dramatic undertone underpinning his work has, however, been challenged by a large body work that will show that these new "Islamic political spaces" (Salvatore 2004: 1014) in many ways reconfigure and enable new forms of citizenship (Khosrokhavar 1997, Modood et. al. 2006, Amiraux \& Jonker 2006, Sunier 1996, Maréchal 2008, Arigita 2006). In documenting these new conjunctions between citizenship and Islam, several ethnographies have, however, have also sought to unearth the effects of this "hyper visibility" (Jeldoft 2013) on Muslims' their everyday lives (Bendixsen 2013: 144, Jouli 2015: 76, Kayicki 2018, de Koning 2016, Rogozen-Soltar 2014), and critically map the sexual dimensions of these continuous "interpellations" (Bracke 2011), which particularly target Muslim women (Selby 2012, Johansen \& Spielhaus 2012). Largely inspired by the recent turn in the anthropology of secularism (Asad 2003, Mahmood 2016), this critical shift has also enabled an important analytical move away from a focus on the ethical and political lives of Muslims, to a more sustained attention onto how the presence of Muslims in Europe triggers a series of contradictions that are internal to dominant models of citizenship (Fernando 2014), such as in the discussions around the (face)veil (Moors 2009, Fadil 2015), the Danish Cartoon Riots (Hervik 2011, Henkel 2010, Kublitz 2010) or unregistered Islamic marriages (Moors, de Koning \& Vroom-Najem 2018, Bowen 2016). 
Critically challenging reigning representations of Muslims as "abject" figures (Ewing 2008, Bunzl 2007, Özyurek 2014) has, however, become particularly daunting since the departure of approximatively five thousand European Muslims to Syria between 2012 and 2015 and the succession of terrorists attacks in the continent since 2015. Anthropologists have traditionally tended to stay away from questions of security and terrorism in order to focus on the overwhelming majority of law-abiding 'good Muslims'. These recent events have, however, compelled several to address these issues, in particular as they have come to deeply reshape the terms of the European scholarly debate, such as in the current discussions on radicalization (Khosrokhavar 2016). A first line of studies has sought to historically trace and critically unpack the discourses and practices of deradicalization (Kundnani 2014, Fadil, de Koning \& Ragazzi 2019). In doing so, these studies have attended to the general transformation of Muslims into suspicious subjects (Schiffauer 2008, Birt 2008), as well as its effects upon their everyday lives (Hussain 2013, Qureishi \& Zeitlyn 2012, de Koning 2019). A few recent anthropological studies have, furthermore, sought to complicate the dominant representations of abject figures such as neo-orthodox Muslims or foreign fighters by analyzing their posture as a form of social critique (Suhr 2015, Alloul 2019), or by offering a complex take on the participation of European Muslims in the Caliphate (Navest, de Koning \& Moors 2016). Yet the capacity to sidestep the overwhelming security lens remains limited, as shown in the aftermaths of the publication of the study of Navest, de Koning \& Moors (2016). Set as an explorative online ethnographic project on marriages of female Dutch Muslim migrants (muhajirat) who left to Syria after 2012, the research was controversially picked up by the national press and one of the researchers was accused of being sympathetic to the jihad. A large debate ensued in the Dutch parliament, and a reflective audit was set up by the University of Amsterdam on issues of transparency and deontology (for a further discussion see Moors 2019). Whereas anthropologists may hold a troubled relationship with the dominant nationalist, 
secularist - or in this case: securitizing - gaze, this latter example shows that circumventing it comes with its own share of risks.

\section{Between moral ambivalence and the Islamic tradition}

A last figure that informs the anthropological literature on Islam in Europe, is that of the Muslim as ethical subject. Deeply entangled into the various power structures and racializing mechanisms sketched in the previous sections, it is virtually impossible to treat Muslims simply as moral subjects (Mahmood 2005, Fassin 2015). Yet anthropologists of Islam in Europe, in particular, have played an important role in trying to uncover these internal dynamics, also largely inspired by the Talal Asad's influential suggestion to treat Islam as a discursive tradition (Amir-Moazami \& Salvatore 2003, McLoughlin 2007).

A first important consequence has been the gradual move away from a national perspective on the public sphere, for a more transnationally situated view on Islam as a "global public space of normative reference and debate" (Bowen 2006: 880). As noted by Bowen (2006), the idea of the Umma entails a "sense of world-wide community" (2006: 822), through the continued physical movement and interconnections across national and linguistic borders in a quest for knowledge (see also Grewal 2014), or in an attempt to fulfil one's religious duties (such as hajj). This results in a plural and hybrid understanding of the public sphere (Göle 2013), wherein Islamic modes of reasoning are seen to co-exist in conjunction with others, and wherein a renewed sense of citizenship becomes articulated through what Armando Salvatore describes as "a notion of intercultural civility" (Salvatore, 2004: 1029, see also Jouili 2015: 196-197, Peter 2006). A subsequent consequence, is the understanding of the Islamic tradition as a distinct repertoire, which is subjected to national attempts at regulation (i.e. the creation of a 'French', 'Belgian' or 'German' Islam), yet also continues to exist independently from these interventions (Bowen 2008). This perspective has also produced richly textured 
ethnographies on the role of knowledge in the self-fashioning process (Groeninck 2017, Jacobsen 2011, Bendixsen 2013), and the construction and reconfiguration of religious authorities and the shari'a in the West (Wesselhoeft 2010, Caeiro 2011, Bowen 2016).

Secondly, this tradition-based approach has also paved the way for an understanding of the self that distinctively demarcates itself from the previously mentioned focus on individualisation (see section three), and which is premised on a liberal self-understanding. Largely inspired by Saba Mahmood's (2015) influential work, studies have documented the perpetual process of remodelling one's behavioural disposition (jihad-an-nafs) in line with the Islamic tradition, through the pursue of virtues such as patience (sabr), the reliance on God (tawakkul), or obedience ('ibada). In many cases, these studies have also sought to show how these agential modes rely on a conception of the self that goes beyond the binary of subordination and resistance (Fernando 2014: 161, Jacobsen 2011). This focus on ethical selfcultivation has, furthermore, been complemented by studies that have attended to the "intersubjective and relational" dimensions of this ethical agency (Jouili 2015: 19, Kayikci 2018) as well as its esoteric and 'invisible' dimensions through the co-constitutive presence of figures such as Jinns, Angels or God (Suhr 2019, Groeninck 2017), something Mikkel Rytter has also called the "technology of the Other" (Rytter 2016). A few studies have also looked at this ethical self-making through the prism of affect, like in the case of Sunni converts into Shi'ism (Lechkar 2012), the shari'a councils (Billaud 2013) or Muslims who move away from Islam(ic) orthodoxy (Fadil 2009 \& 2011). This focus on Muslim ethical self-making has, finally, produced a body of work which has attended to the ways in which Islamic modes of subjection are entangled with other power structures like secularism, liberalism and capitalism. Tarlo and Moors (2013) have, for instance, looked at how the values of modesty are upheld in the Islamic fashion industry which is regulated by a commercialised view on beauty and fashion (see also Unal \& Moors 2012), while Jouili (2014) and El Asri (2014) have sought to 
understand how European Muslims artists and performers face a number of challenges within an industry that is largely structured around to the logic of entertainment. All these different studies show that the commitment to a pious lifestyle is neither straightforward nor complete, but steeped with what several have described as "moral ambivalences" (Clarke 2018, Beekers \& Kloos 2018).

These latter insights are, in several cases, however, also sided by a strong critique on the constitutive weight given to the Islamic tradition, and the focus on Muslim ethical agency. Several scholars have critically challenged this tradition-based approach, suggesting that it disregards the "multiple moral registers" that inform Muslims' ethical agency (Liberatore 2016, Schielke \& Debevec 2012), and produces an overemphasis on (Islamic) difference (Dessing \& Jeldoft 2013, Gélard 2017, Bangstad 2009). While these critiques are laudable in their attempts to avoid a reductionist account of the agency of Muslims, they equally echo the earlier sketched discomforts regarding the constitutive weight of religious, i.c. Islamic, traditions. Downplaying the constitutive weight of the Islamic tradition becomes, in these cases, a way to keep Muslims 'relatable’ or 'ordinary' (see Fadil \& Fernando 2015).

\section{Writing beyond the 'Muslims-are(n't)-like-us' paradigm}

Tell them you know brown boys who cry about the sides of Asad's, Amir's and Hassan's they don't know the complex inner worlds of Summaiyah's and Ayesha's tell them comedies, as well as tragedies how full of life we are how full of love

Suhaiymah Manzoor-Khan (2017)

In her poignant poem "This is not a Humanizing Poem", Suhaiymah Manzoor-Khan compellingly describes a central, and disempowering, expectation that British Muslims like her face in performing their art: offering an insight into the 'ordinariness' of their lives as a 
way to dissipate the fears that surround their presence in Britain. Yet she refuses to oblige: "Because if you need me to prove my humanity I'm not the one that's not human". A double gesture informs Manzoor-Khan's refusal: a refusal of the emotional labor of making her audience feel comfortable about her presence (which at once confirms the unsettling work of slam-poetry and hip-hop), and a refusal of the very script that conditions this 'humanity' that she is expected to prove. In his review essay for this journal, Paul Silverstein also notes how Muslims in Europe have today come to occupy a "racialized slot" (2014: 899). Paraphrasing Michel-Rolph Trouillot's concept of the Savage slot, he uses this term to account for the dual process of marking Muslims as society's abject, and anthropology's exotic other (2014: 365). ${ }^{11}$

In this review I have tried to show how this racialized gaze has informed anthropological scholarship on Islam in Europe. I have done so by documenting how the discipline has consistently attempted at 'speaking back' to the way in which Muslims are turned into abject figures, by restoring their voices, or by disentangling the various (nationalist and secular) modes of governance through which this figure of the abject is produced. I have, however, also argued that this need to 'speak back' at these racialized mechanisms produces its own epistemological entrapments, or as I have called them: impasses, and which revolve around the necessity to demonstrate the adaptability of Islamic forms of mobilization with dominant models of secularism and the difficulty to account for the constitutive weight of the Islamic tradition. Tentatively organized around three key figures, the 'migrant', the 'Islamist' and the 'ethical subject', the different sections of this review have sought to unfold how this double epistemological impasse plays out throughout a concern with integration, secularism and moral ambivalence.

\footnotetext{
${ }^{11}$ One needs to stress that anthropology too contains works that account for Muslims as abject figures, like in the work of Ernest Gellner (1992) or Unni Wikan (2001).
} 
My argument is premised on the claim that scholars of Islam in Europe ought to examine whether and how Islam is being (re)established as an autonomous tradition in a postChristian Europe. Claiming that the Islamic tradition is autonomous doesn't mean that it does so in a uniform way, nor that it is marked by 'difference'. The autonomy of the tradition lies not so much in its alterity (or sameness), but rather in what John Bowen (2006) has described as the distinct "felicity conditions" (2006: 80) in his study on shari'a councils in Britain, and which allow for a particular mode of reasoning to take effect. Addressing the autonomy of the Islamic tradition therefore implies writing beyond the "us" vs. "them" paradigm by examining the complex constitution of this tradition as a "counter-public" (Hirschkind 2001). This counter public remains, so far, largely invisible to the European eye, except through "polemics" (Göle 2013). Documenting its complex articulations of the Islamic tradition the different parts of the continent, thereby counterbalancing the Western-European bias by including Eastern and Southern Europe more fully, will be an important challenge for the years to come. Doing so, will not only strengthen the quality of the existing scholarship, but it will also importantly contribute to redefining what Europe is. 


\section{Bibliography}

Alloul J. 2019. Can the Muhajir Speak? European Syria Fighters and the Digital Un/Making of Home. In Radicalization in Belgiium and the Netherlands. Critical perspectives on violence and security, ed. N Fadil, M de Koning, F Ragazzi, pp. 217-44. London: IB Tauris

Amir-Moazami S, Salvatore A. 2003. Gender, Generation, and the Reform of tradition: From Muslim Majority Societies to Western Europe. In Muslim Networks and Transnational Communities in and Across Europe, ed. S Allievi, J Nielsen, pp. 52-77. Leiden, Boston: Brill

Amiraux, V. 2001. Acteurs de l'Islam entre Allemagne et Turquie. Parcours militants et expériences religieuses. Paris: l'Harmattan

Amiraux V, Jonker G. 2006. Politics of Visibility. Young Muslims in European Public Spaces. . Bielefeld: Transcript Verlag

Andezian S. 1983. Pratiques feminines de l'islam en France. Archives des sciences sociales des religions 28: 53-66

Arigita E. 2006. Representing Islam in Spain: Muslim Identities and the Contestation of Leadership. The Muslim World 96: 563-84

Asad, T. 2003. Formation of the Secular. Christianity, Islam and Modernity. Redwood City: Stanford University Press.

Asad, T. 1993. Genealogies of Religion. Discipline and reason of power in Christianity and Islam Baltimore/London: John Hopkins University Press

Asad, T. 1986. The Idea of an Anthropology of Islam. Washington: Georgetown University. Occasional Papers Series. Center For Contemporary Arab Studies.

Ath-Messaoud M, Gillette A. 1976. L'immigration Algérienne en France. Paris: Editions Entente

Aydin C. 2017. The Idea of the Muslim World. A Global Intellectual History. Cambridge: Harvard University Press

Bangstad S. 2009. Contesting secularism/s. Secularism and Islam in the work of Talal Asad. . Anthropological Theory 9: 188-208

Bava, Sophie. 2003. "Les Cheikhs mourides itinérants et l'espace de la ziyâra à Marseilles " Anthropologie et Sociétes 27(1):149-66.

Barou J. 1985. Islam, facteur de régulation sociale. Esprit 102: 207-15 
Bendixsen, Synnove. 2013. The Religious Identity of Young Muslim Women in Berlin. Leiden: Brill

Beekers D, Kloos D. 2018. Straying from the Straight Path. How Senses of Failure Invigorate Lived Religion. New York / Oxford: Berghahn

Billaud J. 2016 [2013]. Ethics and Affects in British Sharia Councils: "A Simple Way of Getting to Paradise" London: Routledge

Birt J. 2008. Good Imam, Bad Imam:Civic Religion and National Integration in Britain post9/11. The Muslim World 96: 687-705

Boender, W. 2007. Imam in Nederland. Rol, gezag en binding in een geseculariseerde samenleving. Amsterdam Uitgeverij Bert Bakker.

Bowen J. 2006. Beyond Migration: Islam as a Transnational Public Space. Journal of Ethnic and Migration Studies 30: 879-94

Bowen, J. 2008. Why the French don't like the Headscarves: Islam, the State, and Public space. . Princeton: Princeton University Press

Bowen, J. 2016. On British Islam. Religion, Law, and Everyday Practice in Shari'a Councils Princeton / Oxford: Princeton University Press

Bracke S. 2011. Subjects of debate: secular and sexual exceptionalism, and Muslim women in the Netherlands. Feminist Review 98: 28-46

Brown M. 2000. Quantifying the Muslim Population in Europe: conceptual and data issues. International Journal of Social Research Methodology 3: 87-101

Bunzl M. 2007. Anti-Semitism and Islamophobia: Hatreds Old and New in Europe Chicago: Prickly Paradigm Press

Caeiro A. 2011. The making of the fatwa. The production of Islamic legal expertise in Europe. Archives de Sciences Sociales des Religions 155: 81-100

Cannell F. 2006. The Anthropology of Christianity Durham: Duke University Press

Cesari J, McLoughlin S. 2005. European Muslims and the secular state. London: Routledge

Clarke H. 2018. Moral Ambivalence and veiling amongst British Pakistani women in Sheffield. Contemporary Islam 3: 10-19

Coller I. 2011. Arab France. Islam and the Making of Modern Europe, 1798-1831. Berkeley: University of California Press

Dassetto F, Bastenier A. 1984. L'Islam transplanté : vie et organisation des minorités musulmanes de Belgique. Berchem: EPO

Dassetto F, Bastenier A. 1987. Medias U Akbar Louvain-la-Neuve: CIACO

Davidson, Naomi. 2012. Only Muslim. Embodying Islam in Twentieth Century France. Ithaca: Cornell University press

de Koning, Martijn. 2008. Zoeken naar een 'zuivere' Islam. Geloofsbeleving En Identiteitsvorming Van Jonge Marokkaans-Nederlandse Moslims. Amsterdam: Bert Bakker.

de Koning M. 2019. Routinization and Mobilization of injustice: how to live in a regime of surveillance. In Radicalization in Belgium and the Netherlands. Critical perspectives on Violence and Security ed. N Fadil, M de Koning, F Ragazzi, pp. 197-216. London: IB Tauris

Derrida J. 1994. Specters of Marx London: Routledge

Dessing NM, Jeldoft N, Nielsen JS, Woodhead L. 2013. Everyday Lived Islam in Europe. Ashgate: Surrey

Diop M. 1988. Stéréotypes et strategies dans la communuaté musulmane de france. In Les musulmans dans la société française ed. R Leveau, G Kepel, pp. 77-87. Paris: Presses de Sciences Po 
Eade J. 1996. Nationalism, Community and the Islamization of Space in London. In Making Muslim Space in North America and Europe, ed. BD Metcalf, pp. 217-33. Berkeley: University of California Press

el-Zein AH. 1977. Beyond Ideology and Theology: The Search for the Anthropology of Islam. Annual Review of Anthropology 6

El Asri F. 2015. Rythmes et voix d'islam. Une socioanthropologie d'artistes musulmans européens Louvain-la-Neuve: Presses Universitaires de Louvain

Ewing KP. 2008. Stolen Honor. Stigmatizing Muslim Men in Berlin. Redwood City: Stanford University Press

Fadil N. 2009. Managing Affects and Sensibilities. The case of not handshaking and not fasting. Social Anthropology 17: 439-54

Fadil N. 2011. On not/unveiling as an ethical practice. Feminist Review 98: 83-109

Fadil N, Fernando M. 2015. Rediscovering the "everyday" Muslim: Notes on an anthropological divide. Hau. Journal of Ethnographic Theory 5: 59-88

Fadil N, de Koning M, Ragazzi F. 2019. Radicalization in Belgium and the Netherlands. Critical perspectives on violence and security. London: IB Tauris

Fanon F. 2008 [1952]. Black Skin, White Masks. London: Pluto Press

Fassin D. 2015. A Companion to Moral Anthropology. Malden \& Oxford: Wiley Blackwell

Fernando, Mayanthi. 2014. The Republic Unsettled. Muslim French and the Contradictions of Secularism. Durham: Duke University Press

Gellner E. 1992. Postmodernism, Reason and Religion. London: Routledge

Gélard M-L. 2017. L'Islam en France: Pratiques et Vécus du quotidien. Ethnologies Française 168: 599-606

Gilsenan M. 2000 [1982]. Recognizing Islam: Religion and Society in the Moden Middle East. London: IB Tauris

Guénif Souilamas, N. 2000. Des Beurettes Paris: Hachette Littératures

Gonzalez-Quijano Y. 1988. Les 'Nouvelles' Générations issues de l'Immigration Maghrébine et la Question de l'Islam. In Les Musulmans dans la société française, ed. R Leveau, G Kepel, pp. 65-76. Paris: Presses de Sciences Po

Göle N. 2013. Islam and Public Controversy in Europe. London: Routledge

Goody J. 2004. Islam in Europe Cambridge/Malden: Polity Press

Groeninck M. 2017. Reforming the Self, Unveiling the World. Islamic Religious Knowledge Transmission for Women in Brussels' Mosques and Institutes from a Moroccan Background. Leuven: KU Leuven, Unpublished Disseration

Habermas J. 2008. Notes on Post-Secular Society. New Perspectives Quarterly 25: 17-29 Hajjat A, Mohammed M. 2013. Islamophobie. Comment les élites françaises fabriquent le "problème musulman" Paris: La Découverte

Hall, Stuart. 1993. "Old and New Identities, Old and New Ethnicities." Pp. 41-68 in Culture, Globalization and the World-System, edited by Anthony King. London: Macmillan.

Hamès C. 1979. Islam et structures sociales chez les immigrés Soninké en France. Social Compass xxvi: 87-98

Harding S. 1991. Representing Fundamentalism. The problem of the Repugnant 'Other'. Social Research 58: 373-93

Henkel H. 2010. Fundamentally Danish?: The Muhammad Cartoon Crisis as Transitional Drama. Human Architecture: Journal of the Sociology of Self-Knowledge 8: 67-82

Hervik P. 2011. The Annoying Difference. The Emergence of Danish Neonationalism, Neoracism, and Populism in the Post-1989 World New York / Oxford Berghan Books

Hirschkind C. 2001. Civic Virtue and Religious Reason: An Islamic Counterpublic. Cultural Anthropology 16: 3-34 
Hussain A. 2013. Transgressing community: the case of Muslims in a twenty-first-century British city. Ethnic and Racial Studies 37: 621-35

Jacobsen, Christine. 2011. Islamic Traditions and Muslim Youth in Norway. Leiden: Brill.

Jeldoft N. 2013. The Hypervisibility of Islam. In Everyday Lived Islam in Europe, ed. NM Dessing, N Jeldoft, pp. 28-38. Surrey Ashgate

Johansen B, Spielhaus R. 2012. Couting Deviance: Revisiting a Decade's Production of Surveys among Muslims in Western Europe. Journal of Muslims in Europe 1: 81-112

Jouili JS. 2014. Refining the Umma in the Shadow of the Republic: Performing Arts and New Islamic Audio-Visual Landscapes in France. Anthropological Quarterly 87: 1079-104

Jouili, J. 2015. Piouis Practice and Secular Constraints. Women in the Islamic Revival in Europe. Stanford: Stanford University Press.

Kanmaz M. 2009. Islamitische ruimtes in de stad Gent: Academia Press

Kayikci M. 2018. Committing to Society, Committing to God: The Relational Experience of Piety among the Muslim Female Volunteers in Belgium. Leuven: KU Leuven, Unpublished Dissertation

Kastoryano R. 1987. Definition des frontières de l'identité Turcs Musulmans" Revue française de science politique 37: 833-54

Kennedy J, Valenta M. 2006. Religious pluralism and the Dutch state: reflections on the future of Article 23. In Geloven in het publieke domein. Verkenningen van een Dubbele Transformatie ed. WBHJ van de Donck, AP Jonkers, GJ Kronjee, RJJM Plum, pp. 337-52. Amsterdam: Amsterdam University Press

Kepel G. 1991 [1987]. Les banlieues de l'Islam. Naissance d'une religion en France. Paris: Editions du Seuil

Khosrokhavar, F. 1997. l'Islam des Jeunes. Paris: Flammarion.

Khosrokhavar F. 2016. Radicalization. Why Some People Choose the Path of Violence. New York The New Press

Kublitz A. 2010. The Cartoon Controversy: Creating Muslims in a Danish Setting. social Analysis: The International Journal of Social and Cultural Anthropology 54: 107-25

Kuppinger P. 2015. Faithfully Urban. Pious Muslims in a German City New York / Oxford: Berghahn

Kundnani A. 2014. The Muslims are Coming. Islamophobia, extremism and the domestic war on terror. London Verso Books

Norton, Anne. 2013. On the Muslim Question. . Princeton: Princeton University Press

Lacomba, Joan. 2000. "Immigrés sénégalais, islam et confréries à Valence

(Espagne)." Revue Européenne des Migrations Internationales 16(3):85-103.

Lacoste-Dujardin, Camille. 1992. Yasmina et les autres de Nanterre et d'ailleurs. Paris: La Découverte

Lambek M. 2010. Ordinary Ethics. Anthropology, Language an Action. . New York: Fordham University Press

Laurens, Henry, John Tolan, and Gilles Veinstein. 2009. L'Europe et l'islam. Quinze sciècles d'histoire Paris Odile Jacob.

Lechkar I. 2012. Striving and Stumbling in the Name of Allah. Neo-Sunnis and Neo-Shi'ites in a Belgian Context, Leuven: KU Leuven, Unpublished Dissertation

Lewis, Philip. 1994. Islamic Britain: Religion, Politics and Identity Among British Muslims: Bradford in the 1990's. London: I.B. Tauris

Liberatore G. 2016. Imagining an Ideal Husband: Marriage as a Site of Aspiration among Pious Somali Women in London. Anthropological Quarterly 89: 781-812

Lorcerie, Françoise. 2005. La politisation du voile en France, en Europe et dans le monde arabe Paris: l'Harmattan 
Mahmood, S. 2005. Politics of Piety. The Reform of the Feminist Subject. Princeton/Oxford: Princeton University Press.

Mahmood S. 2016. Religious Difference in a Secular Age. A Minority Report. Princeton: Princeton University Press

Mamdani, Mahmood. 2004. Good Muslim, Bad Muslim. America, the Cold War, and the Roots of Terror. New York: Three Leaves Press. Doubleday.

Mandaville P. 2001. Transnational Muslim Politics: Reimagining the Umma London: Routledge

Mandel R. 2008. Cosmopolitan Anxieties Durham: Duke University Press

Malkki, Liisa H. 1995. "Refugees and Exhile: From "Refugee Studies" to the National Order of Things." Annual Review of Anthropology 42:495-523.

Maréchal B. 2008. The Muslim Brothers in Europe. Roots and Discourses. . Leiden: Brill

Martens A. 1973. 25 jaar wegwerparbeiders : het Belgisch immigratiebeleid na 1945. Leuven: KUL Sociologisch onderzoeksinstituut. Afdeling Arbeids- en Industriele Sociologie

Masuzawa T. 2005. The Invention of World Religions, or, How European universalism was preserved in the language of pluralism. Chicago: The University of Chicago Press

Matar, Nabil. 1999. Turks, Moors, and Englishmen in the Age of Discovery. New York: Columbia University Press

McLoughlin S. 2005. Mosques and the Public Space: Conflict and Cooperation in Bradford. Journal of Ethnic and Migration Studies 31: 1045-66

McLoughlin S. 2007. Islam(s) in context: Orientalism and the anthropology of Muslim societies and cultures. Journal of Beliefs \& Values 28: 273-96

Meinert, Lotte, and Bruce Kapferer. 2015. In The Event. Toward an Anthropology of Generic Movements. New York \& Oxford Berghahn Books

Metcalf, Barbara Daly. 1996. Making Muslim Space in North American and Europe Berkeley University of California Press

Meer N. 2013. Racialization and religion: race, culture and difference in the study of antisemitism and Islamophobia. Ethnic and Racial Studies 36 (special issue)

Modood T, Triandafyllidou A, Zapata-Barrero R. 2006. Multiculturalism, Muslims and Citizenship. London: Routledge

Moors A. 2009. The Dutch and the face-veil: The politics of discomfort. Social Anthropology 17: 393-408

Moors A, de Koning M, Vroom-Najem V. 2018. Secular Rule and Islamic Ethics. Engaging with Muslim-Only Marriages in the Netherlands. Sociology of Islam 6: 274-96

Moors A. 2019. No Escape: The Force of the Security Frame in Academia In Radicalization in Belgiium and the Netherlands. Critical perspectives on violence and security, ed. N Fadil, M de Koning, F Ragazzi, pp. 245-61. London: IB Tauris

Nail T. 2015. The Figure of the Migrant. Redwood City: Stanford University Press

Nathan E, Toploski A. 2016. Is there a Judeo-Christian Tradition? A European Perspective. Berlin: De Gruyter

Navest A, de Koning M, Moors A. 2016. Chatting about Marriage with Female Migrants to Syria. Anthropology Today 32: 22-25

Nora P. 1984. Les Lieux de mémoire. Paris: Gallimard

Nordbruch G, Ryad U. 2014. Transnational Islam in Interwar Europe. Muslim Activists and Thinkers New York \& Basingstoke: Palgrave Macmillan

Özyurek E. 2014. Being German, Becoming Muslim: Race, Religion and Conversion in the New Europe Princeton: Princeton University Press

Pedraza S. 1991. Women and Migration: The Social Consequences of Gender. Annual Review of Sociology 17: 303-25 
Qureshi K, Zeitlyn B. 2012. British Musilms, British soldier: Cultural citizenship in the new imperialism. Ethniciites 13: 110-26

Robbins, J. 2003. What is a Christian? Notes toward an anthropology of Christianity. Religion 33:191-99.

Rogozen-Soltar M. 2014. Managing Muslim Visibility: Conversion, Immigration and Spanish Imaginaries of Islam. American Anthropologist 114: 611-23

Roy, Olivier. 2002. L'Islam Mondialisé. Paris: Seuil.

Rytter M. 2013. Family Upheaval. Generation, Mobility and Relatedness among Pakistani Migrants in Denmark. New York: Berghan Books

Rytter M. 2016. By the beard of the Prophet: Imitation, reflection and world transformation among Sufis in Denmark Ethnography 17: 229-49

Salazar N. 2017. Key Figures in mobility: an introduction. Social Anthropology 25: 5-12

Salvatore A. 2004. Making Public Space: Opportunities and Limits of collective Action among muslims in Europe. Journal of Ethnic and Migration Studies 30: 1013-31

Said, Edward W. 1995 [1978] Orientalism. Western Conceptions of the Orient. London: Penguins.

Sayad, Abdelmalek. 1999. La double absence. Des illusions de l'émigré aux souffrances de l'immigré. Paris: Editions le Seuil.

Sayad, Abdelmalek. 2014. L'immigration ou les paradoxes de l'altérité. 3. La fabrication des identités culturelles Paris: Raison d'agir editions

Sayyid, Bobby S. 1997. A fundamental fear: Eurocentrism and the emergence of Islamism. London: Zed.

Sbaï, Jalila. 2018. La politique musulmane de la France. Un projet chrétien pour l'islam? 1911-1954. Paris: CNRS Editions

Schielke S, Debevec L. 2012. Ordinary Lives and Grand Schemes. An Anthropology of Everyday Religion. New York / Oxford: Berghahn Books

Schiffauer W. 2008. Suspect Subjects: Muslim Migrants and the Security Agencies in Germany. In The Social Life of Anti-Terrorism Laws. The War on Terror and the Classifications of the "Dangerous Other", ed. JM Eckert, pp. 55-77. Berlin: Transcript Verlag

Scott, Joan Wallach. 2007. The Politics of the Veil. . Princeton: Princeton University Press

Selby JA. 2012. Questioning French Secularism. Gender Politics and Islam in a Parisian Suburb. New York: Palgrave MacMillan

Silverstein P. 2004. Algeria in France. Bloomington: Indiana University Press

Silverstein, Paul A. 2005. "Immigrant Racialization and the New Savage Slot: Race, Migration, and Immigration in the New Europe." Annual Review of Anthropology 34:363-84.

Spivak GC. 1988. Can the Subaltern Speak? . In Marxism and the Interpretation of Culture, ed. C Nelson, L Grossberg, pp. 271-313. Basingstoke: Macmillan Education

Suhr C. 2015. Brainwashed at School? Deprogramming the Secular among Young NeoOrthodox Muslims in Denmark. In Making European Muslims. Religious Socialization among Young Muslims in Scandinavia and Western Europe ed. M Sedgwick, pp. 249-68. New York \& Abingdon Routledge

Suhr C. 2019. Descending with Angels. Islamic Exorcism and Psychiatry: a film monograph. Manchester: Manchester University Press

Sunier T. 1996. Islam in Beweging. Turkse jongeren en islamitische organisaties Amsterdam: Het Spinhuis

Tarlo, Emma, and Annelies Moors. 2013. "Islamic Fashion and anti-Fashion. New Perspectives from Europe and North America." London/Oxford: Bloomsbury Publishing. 
Truong F. 2018. Radicalized Loyalities. Becoming Muslim in the West. London: Polity

Vakil A, Sayyid S. 2010. Thinking Through Islamophobia. Global Perspectives New York: Columbia University Press

Varisco DM. 2005. Islam Obscured. The Rhetoric of Anthropological Representation. New York: Palgrave MacMillan

Verkaaik O. 2012. Designing the 'anti-mosque': identity, religion and affect in contemporary European mosque design. Social Anthropology 20: 161-76

Vertovec S, Rogers A. 1998. Muslim European Youth. Reproducing Cthnicity, Religion, Culture. Aldershot: Ashgate. 1-24 pp.

Werbner P. 2002 [1990]. The Migration Process. Capital, Gifts and Offerings among British Pakistanis London: Bloomsbury

Wesselhoeft K. 2010. Making Muslim Minds: Question and Answer as a Genre of Moral Reasoning in an Urban French Mosque. Journal of the American Academy of Religion 78: 790-823

Wikan U. 2001. Generous Betrayal. Politics of Culture in the New Europe. Chicago: University of Chicago Press

Willerslev R, Suhr C. 2018. Is there a place for faith in anthropology? Religion, reason, and the ethnographer's divine revelation. Hau. Journal of Ethnographic Theory 8: 65-78

Withol de Wenden C. 1985. L'emergence d'une Force Politique? Les conflits des immigres musulmans dans la cité". Esprit 102: 222-31 